\title{
Applications of Amniotic Membrane and Fluid in Stem Cell Biology and Regenerative Medicine
}

\author{
Kerry Rennie,, ${ }^{1}$ Andrée Gruslin, ${ }^{2,3}$ Markus Hengstschläger, ${ }^{4}$ Duanqing Pei, ${ }^{5}$ Jinglei Cai, ${ }^{5}$ \\ Toshio Nikaido, ${ }^{6}$ and Mahmud Bani-Yaghoub ${ }^{1,2}$ \\ ${ }^{1}$ Neurogenesis and Brain Repair, National Research Council-Institute for Biological Sciences, Bldg. M-54, Ottawa, \\ ON, Canada K1A OR6 \\ ${ }^{2}$ Department of Cellular and Molecular Medicine, Faculty of Medicine, University of Ottawa, Ottawa, ON, Canada KIH 845 \\ ${ }^{3}$ Department of Obstetrics and Gynecology, Faculty of Medicine, University of Ottawa, Ottawa, ON, Canada KIH 845 \\ ${ }^{4}$ Institute of Medical Genetics, Medical University of Vienna, Währinger Straße 10, 1090, Vienna, Austria \\ ${ }^{5}$ Key Laboratory of Regenerative Biology, South China Institute for Stem Cell Biology and Regenerative Medicine, \\ Chinese Academy of Sciences, 190 Kai Yuan Avenue, Science Park, Guangzhou 510530, China \\ ${ }^{6}$ Department of Regenerative Medicine, University of Toyama Graduate School of Medicine and Pharmaceutical Sciences, \\ 2630 Sugitani, Toyama 930-0194, Japan
}

Correspondence should be addressed to Mahmud Bani-Yaghoub, mahmud.bani@nrc.ca

Received 4 June 2012; Accepted 7 September 2012

Academic Editor: Gerald A. Colvin

Copyright ( $) 2012$ Kerry Rennie et al. This is an open access article distributed under the Creative Commons Attribution License, which permits unrestricted use, distribution, and reproduction in any medium, provided the original work is properly cited.

\begin{abstract}
The amniotic membrane (AM) and amniotic fluid (AF) have a long history of use in surgical and prenatal diagnostic applications, respectively. In addition, the discovery of cell populations in AM and AF which are widely accessible, nontumorigenic and capable of differentiating into a variety of cell types has stimulated a flurry of research aimed at characterizing the cells and evaluating their potential utility in regenerative medicine. While a major focus of research has been the use of amniotic membrane and fluid in tissue engineering and cell replacement, AM- and AF-derived cells may also have capabilities in protecting and stimulating the repair of injured tissues via paracrine actions, and acting as vectors for biodelivery of exogenous factors to treat injury and diseases. Much progress has been made since the discovery of AM and AF cells with stem cell characteristics nearly a decade ago, but there remain a number of problematic issues stemming from the inherent heterogeneity of these cells as well as inconsistencies in isolation and culturing methods which must be addressed to advance the field towards the development of cell-based therapies. Here, we provide an overview of the recent progress and future perspectives in the use of AM- and AF-derived cells for therapeutic applications.
\end{abstract}

\section{Introduction}

Regenerative medicine involves the use of living cells to repair, replace, or restore normal function to damaged or defective tissues and organs $[1,2]$. Stem cells are viewed as promising candidates for use in cell-based therapies, owing to their capacity for self-renewal and differentiation into diverse mature progeny. However, the source of stem cells, in order to maximize the safety and efficacy of regenerative therapies, is clearly of great importance. Both adult and embryonic stem cells are commonly used to develop therapies for various preclinical models of disease and injury. Recently, induced pluripotent stem (iPS) cells, which are obtained by genetically reprogramming adult somatic cells to a pluripotent state, have also been proposed as an alternative cell source for use in regenerative medicine $[3,4]$. However, a number of limitations hamper the clinical applicability of stem cells derived from either adults or developing embryos. While embryonic stem cells (ES cells) are highly proliferative and capable of differentiating into cells of all adult tissues, they pose a significant risk of tumour formation [5]. Furthermore, since ES cells are obtained by the destruction of embryos, they face serious ethical objections that have yet to be resolved. In contrast, although adult stem cells carry a reduced risk of tumorigenicity and fewer ethical restrictions, they are limited in number, have diminished differentiation 
TABLE 1: Comparison of ES, AM and AF stem cells.

\begin{tabular}{|c|c|c|c|c|}
\hline & Embryonic stem cells & Amniotic epithelial cells & $\begin{array}{l}\text { Amniotic mesenchymal } \\
\text { stromal cells }\end{array}$ & Amniotic fluid cells \\
\hline Source & $\begin{array}{l}\text { Inner cell mass of } \\
\text { preimplantation embryo }\end{array}$ & Amniotic membrane & Amniotic membrane & Amniotic fluid \\
\hline In vitro lifespan & $\begin{array}{l}300+\text { population } \\
\text { doublings }[48]\end{array}$ & $\begin{array}{l}14 \text { population doublings } \\
\text { [49] }\end{array}$ & $\begin{array}{l}5-10 \text { passages }[50], 27 \\
\text { population doublings }[51]\end{array}$ & $\begin{array}{l}55[52] \text { to } 250+[14] \\
\text { population doublings }\end{array}$ \\
\hline $\begin{array}{l}\text { Differentiation } \\
\text { potential in vitro }\end{array}$ & $\begin{array}{l}\text { Ectodermal, mesodermal, } \\
\text { endodermal [53] }\end{array}$ & $\begin{array}{l}\text { Ectodermal, mesodermal, } \\
\text { endodermal }[20]\end{array}$ & $\begin{array}{l}\text { Ectodermal, mesodermal, } \\
\text { endodermal }[20]\end{array}$ & $\begin{array}{l}\text { Ectodermal, mesodermal, } \\
\text { endodermal [14] }\end{array}$ \\
\hline Tumorigenicity & Yes [54] & No [15] & Not known & No [14] \\
\hline Ethical issues & Yes & No & No & No \\
\hline Clinical trials & Yes [55] & Yes [56] & No & No \\
\hline
\end{tabular}

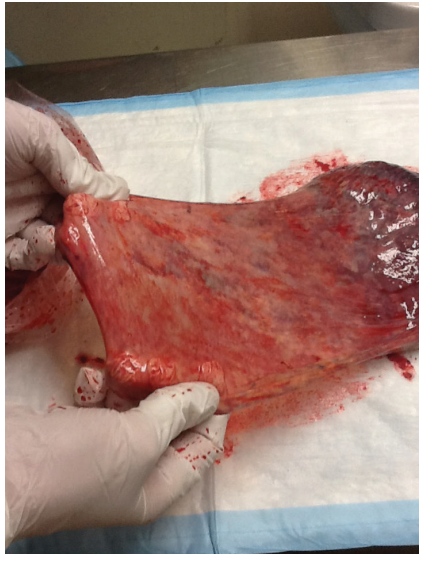

(a)

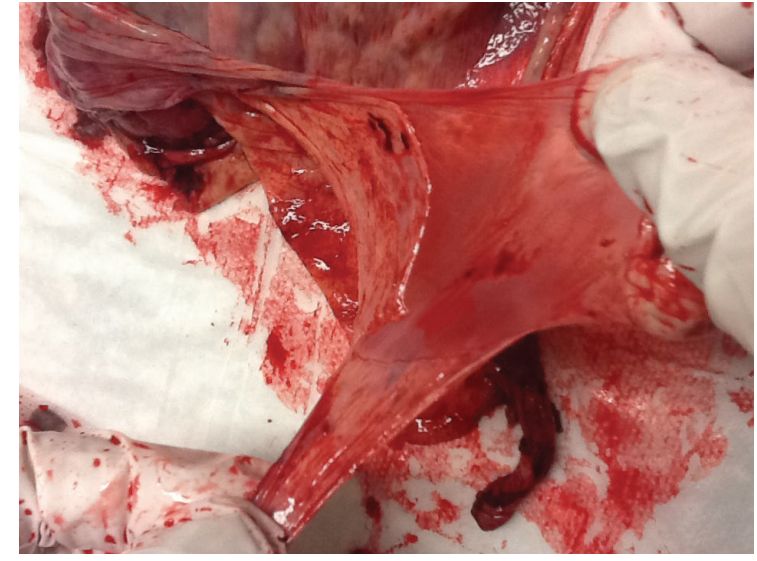

(b)

FIgURE 1: The isolation of human fetal membranes from the placenta. (a) Note the texture and elasticity of the membranes. (b) Human amniotic (left) and chorionic (right) membranes can be readily separated from each other for further purification procedures.

capacity, and reduced proliferative potential $[6,7]$ which render the production of a sufficient number of cells for use in cell-based therapy difficult. Finally, despite major advances in iPS technology in recent years, reprogrammed cells often have an imperfectly cleared epigenetic memory of the source cells [8]. In addition, iPS cells are vulnerable to genomic instability $[9,10]$. Due to the drawbacks associated with ES cells, adult stem cells and iPS cells, much effort has been directed at finding an alternative source of cells for use in regenerative medicine.

Subpopulations of multipotent cells exist in both the amniotic membrane (AM) and amniotic fluid (AF). Amniotic fluid cells are obtained during amniocentesis, an important diagnostic procedure performed worldwide to evaluate the health status of the fetus during pregnancy. Amniotic epithelial (AE) and amniotic mesenchymal stromal (AMS) cells are isolated from amnion that is normally discarded following birth. These cells are therefore readily available, easily procured, and avoid the ethical issues that are associated with the use of ES cells. Subpopulations of AFand AM-derived cells with stem cell characteristics can be maintained in the undifferentiated state in culture, but are capable of differentiating into cells representing all three germ layers under appropriate conditions [11, 12]. Unlike ES cells, AF and AE cells have not been found to form teratomas when transplanted in vivo [11, 13-16], and may be a safer alternative to ES cells. A comparison of AF, AE and AMS stem cells with ES cells is provided in Table 1. The use of amniotic fluid- and membrane-derived cells as cell-based therapy for a variety of indications has been extensively explored in the past decade. Here, we briefly review the findings regarding the use of $\mathrm{AM}$ and $\mathrm{AF}$ in tissue engineering and cell replacement strategies in a number of injury and disease models.

\section{Amniotic Membrane}

2.1. Amniotic Membrane Is a Natural Scaffold with Multiple Clinical Applications. Human amniotic membrane (Figure 1) is the innermost fetal layer, lining the amniotic cavity and protecting the fetus during pregnancy. The outer layer, termed chorionic membrane, further separates the fetus from maternal tissues. Reports focusing on the physiological functions of fetal layers have shown that amniotic membrane not only provides a physical support for the fetus, but also serves as a metabolically active filter through a direct interaction with amniotic fluid. In particular, the transport of water and soluble materials as well as the production of 
growth factors, cytokines, and other bioactive molecules are regulated by amniotic membrane [17]. In addition to its role during pregnancy, amniotic membrane allows the initiation and maintenance of uterus contraction at birth [18].

The translucent, avascular, low immunogenic, antiinflammatory, antiscarring, and wound healing properties of amniotic membrane allow this material function beyond its role in vivo and assume a wide range of applications in regenerative medicine $[19,20]$. In fact, the clinical use of amniotic membrane has a long history, with the first reports on its application in treatment of skin burns and wounds more than a century ago [21-23]. These groundbreaking studies played a significant role in advancing the use of amniotic membrane in surgery, especially in areas such as reconstruction of the corneal and conjuctival surfaces, treatment of open ulcers and traumatic wounds, and skin transplantation $[17,20,24,25]$. In parallel, the shelf life of amniotic membrane has been extended by irradiation, air-drying, lyophilization, cryo-preservation, and glycerol preservation techniques. These methods are expected to further expand the use of amniotic membrane in ophthalmology to treat corneal, conjunctival and limbal lesions, burns, scars and defects as well as general surgery to reconstruct skin, genitourinary tract and other surfaces [2531]. However, the efficacy of amniotic membrane in clinical applications can only be enhanced by retaining its biological properties in the long term. This issue is especially important because the presence of key growth factors such as EGF, FGF, TGF, HGF in amniotic membranes may account for their clinical effects and mechanisms of action. Currently, a series of standardized guidelines are being developed in a number of countries to optimize the production of surgically suitable amniotic membrane from donor placenta.

2.2. Stem Cells in Amniotic Membrane. In addition to these strategies, various histological, biochemical, and cellular biology techniques have been used to isolate and determine the suitability of the cells in amniotic membrane for other clinical applications. Epithelial cells can be readily identified as a single layer adjacent to the amniotic fluid on one side and the basement membrane on the other side $[17,32$, 33]. While epithelial cells reside on the inner layer of the amniotic membrane, mesenchymal stromal cells form the outer layer $[17,32,33]$. Both cell types have been extensively investigated for their biological properties, using a number of in vitro and in vivo models. In particular, the expression of several cellular and molecular markers has confirmed the presence of stem cells in epithelial and mesenchymal stromal cultures. Subpopulations of both AE cells and AMS cells express pluripotency markers, including OCT4, SOX2, and NANOG $[13,15,34,35]$. AE cells express embryonic stem cell markers such as SSEA4, TRA-1-60, and TRA1-81 [13, 36], while reports on the expression of ES cell markers by AMS cells have been inconsistent [20]. Technical issues have prevented researchers from determining whether a single human AE or AMS (hAE or hAMS) cell can differentiate into cells representative of all three germ layers after clonal expansion [37]; therefore, it remains unclear whether the human amnion harbours true pluripotent stem cells, or a mixed population of multipotent progenitor cells. Nevertheless, it is widely accepted that multiple cell types can be derived by culturing either AE or AMS cells under appropriate conditions. Several laboratories have reported neural $[13,15,35,38,39]$, hepatic $[13,15,40-43]$, cardiac $[15,34,44]$, osteogenic $[15,45,46]$, chondrogenic $[39,47]$ and adipogenic $[15,46]$ differentiation of both AE and AMS cells.

2.3. Amniotic Membrane-Derived Cells in Tissue Engineering and Cell Replacement. The development of biological substitutes to replace damaged or dysfunctional tissue may involve the construction of "replacement parts" in vitro for later transplantation, or the direct administration of cells to the damaged tissue [57]. AE and AMS cells have been employed for both purposes. For instance, after inducing osteogenic differentiation of human AMS cells seeded onto microcarriers, the resulting bone-like structures could be used as building blocks to form a large $(2 \times 1 \mathrm{~cm})$ bone construct in vitro [58]. AE cells have been used to form tendon-like structures [59], and a double-layered skin graft (using both AE and AMS cells) capable of repairing skin defects in mice [60]. Human AE and AMS cells have also been shown to reduce liver damage in a chemically-induced model of cirrhosis $[61,62]$ and improve cardiac function after experimental cardiac infarction [34, 44, 63]. Furthermore, both AE and AMS cells were able to replace insulinproducing pancreatic beta cells in diabetic mice to restore normal glucose levels [64-66]. Comprehensive reviews of the differentiation potential and therapeutic use of AE and AMS cells in experimental models are available in the literature [18, 20, 37, 67-69].

\section{Amniotic Fluid}

3.1. Amniotic Fluid Is a Dynamic Environment Containing Diverse Cell Types. Human amniotic fluid is a dynamic environment, which undergoes multiple developmental changes in order to sustain fetal growth and well being (Figure 2). The amniotic cavity first appears at 7-8 days after fertilization and in early gestation the amniotic fluid originates mostly from maternal plasma that crosses the fetal membranes [70]. Fetal urine first enters the amniotic space at 8-11 weeks gestation [70], and in the second half of pregnancy, fetal urine becomes the major contributor to amniotic fluid [71]. At this time, fetal skin keratinisation is complete, leading to reduced water transport across the skin and a decrease in AF osmolality. For the remainder of gestation, fluid volume is determined by different mechanisms including fetal urine production, oral, nasal, tracheal and pulmonary fluid secretion, fetal swallowing, and the contributions of the intramembranous pathway [72].

Amniotic fluid contains electrolytes, growth factors, carbohydrates, lipids, proteins, amino acids, lactate, pyruvate, enzymes, and hormones [73-76]. In addition, fluid secretions from the fetus into the AF carry a variety of fetal cells, resulting in a heterogeneous population of cells derived from fetal skin, gastrointestinal, respiratory and urinary tracts, and the amniotic membrane [77]. As the fetus develops, 


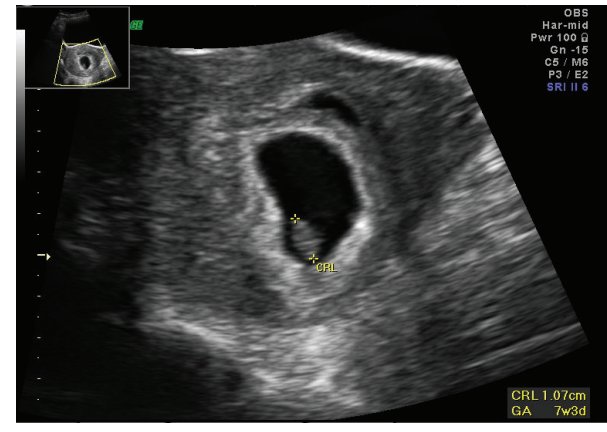

(a)

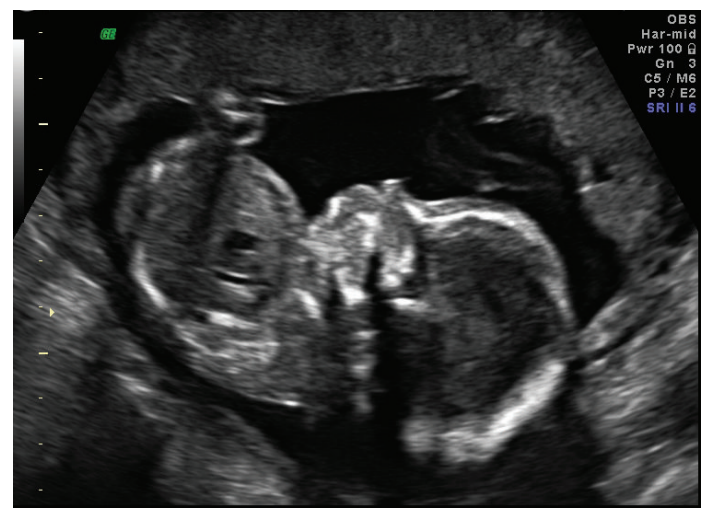

(c)

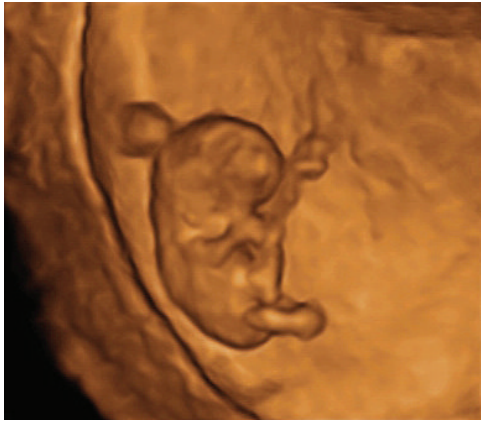

(b)

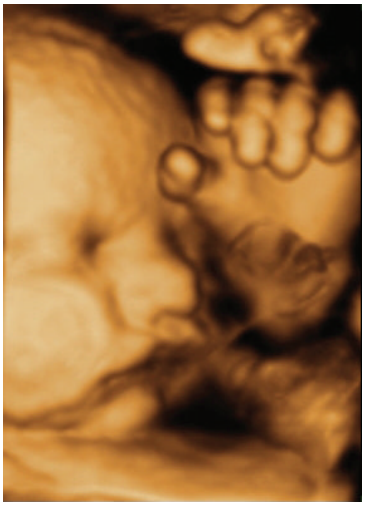

(d)

Figure 2: ((a)-(b)) 2D (a) and 3D (b) ultrasound images of a human embryo in the first trimester. Note the relative amount of amniotic fluid compared to the size of the embryo. The fluid is mostly derived from maternal plasma at this gestational age. ((c)-(d)) A 2D ultrasound image of the fetus at 20 weeks (c) and a 3D ultrasound image of the fetal head at 36 weeks (d). Fetal urine is the main contributor to the fluid at this gestational age. Note the difference in proportion of amniotic fluid in the first (a) and second (c) trimesters.

the volume and composition of the amniotic fluid change drastically, and the complement of cells detected in amniotic fluid samples taken at different gestational ages varies considerably $[78,79]$.

Despite this heterogeneity, cultures of amniotic fluid cells obtained by amniocentesis have been used for decades for diagnostic purposes, including standard karyotyping as well as other genetic and molecular tests. AF samples are routinely used in the evaluation of fetal lung maturity, metabolic diseases, fetal infections, and intrauterine infections. These tests have recently been complemented by applying chromosomal microarray (CMA) as a more efficient prenatal genetic screening tool to detect fetal abnormalities [80]. In this multicenter study, nearly $4400 \mathrm{AF}$ samples were used to assess the performance of CMA compared with karyotyping for prenatal cytogenetic diagnosis. Interestingly, CMA analysis allowed the detection of additional genetic abnormalities in about 1 out of every 70 samples that reported a normal karyotype during routine prenatal diagnosis. These results further emphasize the importance of AF cells in providing clinically important information about the fetus. In addition, this technology can be used to routinely follow the status of different subpopulations of amniotic fluid cells in culture and identify the most suitable clones for cell-based therapies.
Generation and banking of monoclonal human AF stem cell lines with specific chromosomal aberrations or monogenic disease mutations may also help study the functional consequences of disease-causing mutations [81, 82]. As a promising approach, the use of prolonged siRNA-mediated gene silencing in AF stem cells [83] may advance our understanding of the functions of specific genes and shed light on the pathogenesis of certain naturally occurring diseases [84].

3.2. Stem Cells in Amniotic Fluid. The fact that amniotic fluid is commonly collected for routine diagnostic testing and is a widely accessible source of fetal cells, prompted an interest in examining the possibility that AF might contain multipotent fetal-derived cells [85]. In 2003, Prusa et al. discovered the existence of a small population of actively dividing cells in human amniotic fluid which express OCT4, a marker of pluripotent stem cells, as well as stem cell factor, vimentin and alkaline phosphatase [86]. In the same year, In 't Anker et al. reported the isolation of mesenchymal stem cells with multilineage differentiation capacity from amniotic fluid [87]. A subsequent study used immunoselection for c-kit (CD117, receptor for stem cell factor) to isolate a population of cells with high self-renewal capacity that expressed some common ES cell markers (OCT4 and SSEA4) as well as markers of somatic stem cells (CD29, CD44, 
CD73, CD90, and CD105) that are not typically detected in ES cells [14]. Several AF-derived clonal cell lines were established that exhibited the capability to differentiate into cell types from all three germ layers (including adipogenic, osteogenic, myogenic, endothelial, neurogenic, and hepatic cells) [14]. A number of other studies have also investigated the differentiation capacity of clonal AF-derived cells [8893]. However, evaluation of the differentiation potential of AF-derived cells has relied heavily on expression of selected markers. Thus, further research is required to demonstrate that differentiated cells are capable of acquiring functional characteristics of the desired cell type, especially in vivo.

\subsection{AF Cells in Tissue Engineering and Cell Replacement.} Because they are readily accessible, pose little to no ethical concerns, and do not form teratomas in vivo, amniotic fluidderived cells have been investigated as a promising alternative source of cells for use in tissue engineering and cell-based therapies. Kaviani et al. first demonstrated that mesenchymal cells from ovine or human AF could be seeded on synthetic scaffolds, as a prelude to using these cells for tissue engineering $[94,95]$. Since that time, amniotic fluid-derived cells have been used in experimental settings to repair different tissues, including cartilage grafts for fetal tracheal reconstruction [96], tendons for diaphragm repair [97, 98], bone grafts [99-101], and heart valve leaflet [102-104]. In vivo administration of amniotic fluid-derived cells as a strategy for cell replacement has had beneficial effects in various injury models, including acute bladder injury [105], acute tubular necrosis of the kidney [106], hyperoxic lung injury [107] and ischemic heart [108]. The use of AF cells in tissue engineering and cell replacement has been extensively reviewed elsewhere $[11,12,20]$ and is summarized in Table 2.

\section{Complementary Applications of AE, AMS, and AF Cells}

4.1. Paracrine Action of AF- and AM-Derived Cells in Tissue Repair. A common theme among several studies attempting to use AF, AE, or AMS cells for tissue repair in injury models is that, despite improving organ function, these cells often do not differentiate into the desired cell type or integrate fully into the target tissues $[105,129]$. This issue may be particularly pertinent in neural applications, since the ability of AF-derived stem cells to differentiate into neurons has been a matter of debate $[130,131]$ and definitive evidence that AF, AE, or AMS stem cells can be induced to become mature functional neurons in vivo is still lacking. Nevertheless, the use of amniotic membrane- and fluidderived cells for nervous system repair has met with some success. c-kit+ AF cells injected into injured chick embryo spinal cord increased embryo survival and reduced injuryinduced haemorrhaging, although the cells failed to undergo terminal differentiation into neurons [132]. Pan et al. [113, 114] reported that AF-derived mesenchymal stromal cells improved motor function and electrophysiological indicators of nerve function in a sciatic nerve crush model, in the absence of stem cell penetration into the nerve. AF cells have also been shown to improve memory and sensory/motor functions following focal ischemia induced by middle cerebral artery occlusion (MCAO) in mice as soon as 4 days after cell injection [109]. Although the fate of the injected cells was not examined in that study, it is doubtful that AF cells could have differentiated into mature neurons capable of effectively integrating into the host circuitry to restore function on such a short time scale. Therefore, it is unlikely that cell replacement could directly account for the beneficial effects of AF cells in this study. In a rat model of Parkinson's disease, implantation of $\mathrm{AE}$ cells into rat striatum prevented the degeneration of nigrostriatal dopaminergic neurons, when administered prior to the neurotoxin 6-OHDA [133], and attenuated motor disturbances in rats that had previously been subjected to 6-OHDA-induced degeneration [134]. Subsequent work showed that administration of AE cells into the lateral ventricle had a similar effect, which was maintained over 10 weeks despite the fact that the majority of the transplanted cells either did not survive, or did not exhibit a dopaminergic phenotype at the end of the experiment [135]. These results further suggest that the positive effect of the transplanted AE cells was not due to their ability to replace lost nigrostriatal neurons.

In a number of cases, the favourable outcomes observed after AF or AM cell transplants have been attributed not to the direct replacement of lost cells, but rather to factors secreted by the cells which may serve a protective or reparative function. Such paracrine mechanisms have also been postulated to explain some of the positive effects of other stem cell types in animal models of organ/tissue injury [136-138]. Studies in which conditioned media (CM), rather than AF or AM cells themselves, have been used in injured tissues support the notion that secreted factors mediate, at least in part, the beneficial effects of the transplanted cells. For instance, AF-CM [139] and AMS-CM [140] both reinstated blood flow in a murine hindlimb ischemia model, and AF-CM increased perfusion to an ischemic skin flap [141] likely owing to the presence of proangiogenic growth factors and cytokines, including VEGF, SDF-1, and TGF- $B$ present within the media. AF-CM was also shown to stimulate other endogenous repair mechanisms, such as proliferation of dermal fibroblasts near the injury site in a mouse excision wound model [142] and recruitment of endothelial progenitor cells to ischemic skin flap [141]. Other paracrine mechanisms, such as the production of trophic factors [114, 143], immunomodulation [144, 145], and creation of a supportive milieu for regeneration [146] might also contribute to the ability of AF- or AM-derived cells to limit damage and/or stimulate repair of injured tissue.

\subsection{AF- and AM-Derived Cells for Delivery of Beneficial} Factors. Although AF- and AM-derived cells appear to have natural protective and reparative functions, they may also be used for efficient biodelivery of specific factors to enhance the protection or repair of damaged tissue through genetic modification. Accordingly, it was recently reported that AF mesenchymal stromal cells engineered to express elevated levels of GDNF ameliorated motor deficits in rats subjected to sciatic nerve crush, beyond the improvement observed 
TABLE 2: Applications of AF stem cells.

\begin{tabular}{|c|c|c|c|c|}
\hline AF cell source & Target tissue & Animal/disease model & Delivery route & References \\
\hline Human & Brain & Normal and twitcher neonatal mice & Intracerebroventricular injection & {$[14]$} \\
\hline Human & Brain & Mouse cerebral ischemia & Intracerebroventricular injection & [109] \\
\hline Human & Brain & Rat cerebral ischemia & Intrastriatal injection & [110] \\
\hline Rat & Brain & Rat cerebral ischemia & Intravenous injection into the jugular vein & {$[111]$} \\
\hline Human & Brain & Mouse motor cortex injury & $\begin{array}{l}\text { Injection or implantation of cells seeded on } \\
\text { biocompatible scaffolds into the motor cortex }\end{array}$ & {$[112]$} \\
\hline Human & Nerve & Rat sciatic nerve crush injury & $\begin{array}{l}\text { Injection or implantation of cells and fibrin glue } \\
\text { into the injury site }\end{array}$ & {$[113-117]$} \\
\hline Human & Nerve, Muscle & Rat sciatic nerve crush injury & Intravenous injection & {$[118]$} \\
\hline Human & Heart & Rat cardiac infarction & $\begin{array}{l}\text { Intracardiac injection of cells or cell sheet } \\
\text { fragments }\end{array}$ & {$[119,120]$} \\
\hline Rat & Heart & Rat cardiac infarction & Intracardiac injection & $\begin{array}{l}{[108,121} \\
122]\end{array}$ \\
\hline Human & Lung, Heart & $\begin{array}{l}\text { Rat pulmonary hypertension and } \\
\text { heart failure }\end{array}$ & Intravenous injection into the tail vein & {$[123]$} \\
\hline Sheep & Heart valve & Fetal sheep & $\begin{array}{l}\text { Closed-heart implantation of cells seeded on } \\
\text { biodegradable scaffolds in utero }\end{array}$ & {$[104]$} \\
\hline Mouse & Skeletal muscle & Mouse spinal muscular atrophy & Intravenous injection into the tail vein & {$[124]$} \\
\hline Human & Bone & Mouse subcutaneous implantation & $\begin{array}{l}\text { Subcutaneous implantation of cells printed on } \\
\text { biocompatible polymers }\end{array}$ & {$[14]$} \\
\hline Rabbit & Bone & Rabbit chest wall/sternal defects & $\begin{array}{l}\text { Bone graft implantation of cells seeded on } \\
\text { biocompatible scaffolds into the injury site }\end{array}$ & {$[99]$} \\
\hline Human & Bone & Rat subcutaneous implantation & $\begin{array}{l}\text { Subcutaneous implantation of cells seeded on } \\
\text { biocompatible polymers }\end{array}$ & {$[101]$} \\
\hline Sheep & Cartilage & Fetal lamb tracheal reconstruction & $\begin{array}{l}\text { Tracheal implantation of cells seeded on } \\
\text { biocompatible scaffolds in utero }\end{array}$ & {$[96]$} \\
\hline Sheep & Diaphragm & Postnatal sheep diaphragmatic hernia & $\begin{array}{l}\text { Diaphragmatic implantation of cells seeded on } \\
\text { biocompatible scaffolds }\end{array}$ & {$[97]$} \\
\hline Human & Kidney & Mouse kidney acute tubular necrosis & Injection into the renal cortex & {$[106]$} \\
\hline Rat & Bladder & Rat cryo-injured bladder & Intravascular injection & {$[105]$} \\
\hline Rat & Abdomen & Rat & Intraperitoneal injection & {$[125]$} \\
\hline Rabbit & Fetal membranes & $\begin{array}{l}\text { Fetal rabbit iatrogenic membrane } \\
\text { defect }\end{array}$ & $\begin{array}{l}\text { Injection into the plug followed by fixation to } \\
\text { the fetal membranes }\end{array}$ & {$[126]$} \\
\hline Sheep & Nonspecific & Fetal lamb organs & Injection into the fetal peritoneal cavity in utero & {$[127]$} \\
\hline Mouse, Human & Hematopoietic & Mouse & Intravenous injection into the retro-orbital vein & {$[128]$} \\
\hline
\end{tabular}

with green fluorescent protein (GFP)-transduced cells [147]. To extend this research to CNS applications, we are currently assessing the neuroprotective capacity of GDNF-expressing AF cells in a mouse motor cortex injury model (unpublished data). Both AE [148] and AMS [149] cells have also been used to deliver neurotrophic factors (GDNF and BDNF, resp.) to ischemic rat brain, and in both cases, enhanced recovery using GDNF- or BDNF-expressing cells was observed, relative to GFP-expressing cells.

AF- and AM-derived cells might be suitable for delivery of diverse compounds for a variety of diseases. For instance, a handful of recent studies have made use of AF cells for biodelivery of anticancer therapeutics. Yin et al. engineered AF mesenchymal stromal cells to express the antiangiogenic factor endostatin and the prodrug-activating enzyme secretable carboxylesterase 2 (sCE2) to treat glioma. sCE2 converts the antitumour drug CPT11 into its active form.
By injecting the engineered cells along with glioma-forming cells prior to treatment with CPT11, the AF cells boosted the conversion of the prodrug to its active form selectively at the tumour site, inhibiting proliferation, increasing apoptosis, and decreasing the population of glioma stem cells [150]. Similarly, expression in AF cells of cytosine deaminase and thymidine kinase, which act as suicide genes by converting two cancer prodrugs to their active toxic forms, inhibited the growth of breast tumours in a xenograft mouse model and prevented both the damage to the surrounding tissue and the physical side effects that were observed when the active drugs were directly administered [151]. These studies highlight a potential role for AF cells in biodelivery of a wide range of compounds.

Presumably, all of the above-mentioned studies have relied on bulk release of secreted factors into the extracellular space to mediate the beneficial effects of AF or AM cells. 
However, we are also investigating the possibility that $\mathrm{AF}$ cells could be used for direct cellular delivery of certain types of molecules via gap junctional communication, as has been suggested by Brink et al. [152] for bone marrow mesenchymal stromal cells. AF cells express connexins, the proteins that make up gap junction hemichannels, and are capable of establishing gap junctional communication with cultured cortical cells, as evidenced by dye transfer [112]. Given the induction of connexin expression surrounding a surgical lesion to motor cortex, [112] as well as in other models of brain injury [153-155], it is hoped that AF cells might be capable of delivering small molecules through gap junctions to host cells, in an effort to protect the surrounding tissue or promote repair mechanisms.

\section{Current Limitations in the Use of AM and AF Cells}

Recent evidence suggests that diverse subpopulations of multipotent cells in amniotic fluid differ in marker expression, morphology, and/or growth kinetics [16, 156]. Furthermore, amniotic membrane-derived cells are not as homogeneous as previously thought. Different culture conditions and methods for isolating and expanding cells with stem cell characteristics might introduce a bias towards producing particular subpopulations of cells [11]. In addition, the gestational stage at which AF is collected [79] and the passage number of the cultured cells [157] will likely influence the resulting cell phenotypes and behaviour. At present, it is not clear exactly what effects these methodological differences have on the outcome of studies, but there is an agreement that cells used by different research groups may not represent identical biological properties. While this renders the comparison of different studies very difficult, it also prompts the question of whether different subpopulations of multipotent cells in AF and AM have distinct differentiation capacities. There is, in fact, some evidence that this is the case [156, $158,159]$. Further exploration of this issue is required, and hopefully it will be possible to exploit these differences to isolate cells with greater potential to differentiate into desired functional cell types. This should be done in conjunction with an examination of the role of culture conditions in directing $\mathrm{AF}, \mathrm{AE}$, and $\mathrm{AMS}$ cell differentiation towards particular cell fates.

Furthermore, it is possible that predifferentiation of AFor AM-derived cells toward a desired phenotype prior to transplantation might promote engraftment in some tissues $[160,161]$. This issue warrants further investigation, especially considering the low rate of differentiation of transplanted AM- or AF-derived cells observed in many studies.

Finally, although AM and AF-derived cells reportedly possess low immunogenicity and can survive transplantation into xenogeneic or allogeneic hosts $[14,20,61,62,146$, 162 ], one study found that AF cells were rejected upon transplantation into immunocompetent animals due to the recruitment of host $\mathrm{T}$ and $\mathrm{B}$ lymphocytes, natural killer cells and macrophages [163]. In another case, poor survival of amniotic epithelium grafts was observed in mice that received repeated transplants, because of immune rejection [164]. Other studies have also reported a low rate of survival of transplanted AF cells $[114,165,166]$, which may be a result of immune rejection. Thus, as for ES cells, whose status as immune-privileged has been questioned [167], further research is required in order to understand the immunological properties of AM- and AF-derived cells, and to enhance graft survival.

Future Perspectives. There is a need for the establishment of national and international registries of cell lines derived from amniotic membrane and fluid in order to make these lines available to researchers worldwide. This strategy will facilitate the development of guidelines for the derivation and characterization of new cell lines and provide detailed protocols for culturing and differentiating existing lines. It is expected that the proposed approach would reduce methodological variabilities, which are compounded by the inherent heterogeneity of amniotic cells. In addition, the creation of a library of information pertaining to the research and (pre)clinical use of AF, AE, and AMS cells would allow researchers to choose the most appropriate cell line for a particular application, hopefully leading to more rapid development of effective regenerative therapies.

\section{Acknowledgment}

The authors thank Anna Jezierski and Brandon Smith for their thoughtful comments and suggestions on the paper.

\section{References}

[1] K. R. Chien, "Regenerative medicine and human models of human disease," Nature, vol. 453, no. 7193, pp. 302-305, 2008.

[2] D. J. Polak, "Regenerative medicine. Opportunities and challenges: a brief overview," Journal of the Royal Society Interface, vol. 7, supplement 6, pp. S777-S781, 2010.

[3] T. Graf and T. Enver, "Forcing cells to change lineages," Nature, vol. 462, no. 7273, pp. 587-594, 2009.

[4] C. J. Lengner, "IPS cell technology in regenerative medicine," Annals of the New York Academy of Sciences, vol. 1192, pp. 3844, 2010.

[5] U. Ben-David and N. Benvenisty, "The tumorigenicity of human embryonic and induced pluripotent stem cells," Nature Reviews Cancer, vol. 11, no. 4, pp. 268-277, 2011.

[6] M. Mimeault and S. K. Batra, "Concise review: recent advances on the significance of stem cells in tissue regeneration and cancer therapies," Stem Cells, vol. 24, no. 11, pp. 2319-2345, 2006.

[7] J. Hipp and A. Atala, "Sources of stem cells for regenerative medicine," Stem Cell Reviews, vol. 4, no. 1, pp. 3-11, 2008.

[8] Y. Ohi, H. Qin, C. Hong et al., "Incomplete DNA methylation underlies a transcriptional memory of somatic cells in human iPS cells," Nature Cell Biology, vol. 13, no. 5, pp. 541549, 2011.

[9] M. A. Blasco, M. Serrano, and O. Fernandez-Capetillo, "Genomic instability in iPS: time for a break," The EMBO Journal, vol. 30, no. 6, pp. 991-993, 2011. 
[10] D. A. Robinton and G. Q. Daley, "The promise of induced pluripotent stem cells in research and therapy," Nature, vol. 481, no. 7381, pp. 295-305, 2012.

[11] P. A. Klemmt, V. Vafaizadeh, and B. Groner, “The potential of amniotic fluid stem cells for cellular therapy and tissue engineering," Expert Opinion on Biological Therapy, vol. 11, no. 10, pp. 1297-1314, 2011.

[12] S. Joo, I. K. Ko, A. Atala, J. J. Yoo, and S. J. Lee, "Amniotic fluid-derived stem cells in regenerative medicine research," Archives of Pharmacal Research, vol. 35, no. 2, pp. 271-280, 2012.

[13] T. Miki, T. Lehmann, H. Cai, D. B. Stolz, and S. C. Strom, "Stem cell characteristics of amniotic epithelial cells," Stem Cells, vol. 23, no. 10, pp. 1549-1559, 2005.

[14] P. De Coppi, G. Bartsch, M. M. Siddiqui et al., "Isolation of amniotic stem cell lines with potential for therapy," Nature Biotechnology, vol. 25, no. 1, pp. 100-106, 2007.

[15] S. Ilancheran, A. Michalska, G. Peh, E. M. Wallace, M. Pera, and U. Manuelpillai, "Stem cells derived from human fetal membranes display multilineage differentiation potential," Biology of Reproduction, vol. 77, no. 3, pp. 577-588, 2007.

[16] S. Zhang, H. Geng, H. Xie et al., "The heterogeneity of cell subtypes from a primary culture of human amniotic fluid," Cellular and Molecular Biology Letters, vol. 15, no. 3, pp. 424439, 2010.

[17] A. C. Mamede, M. J. Carvalho, A. M. Abrantes, M. Laranjo, C. J. Maia, and M. F. Botelho, "Amniotic membrane: from structure and functions to clinical applications," Cell and Tissue Research. In press.

[18] A. Toda, M. Okabe, T. Yoshida, and T. Nikaido, "The potential of amniotic membrane/amnion-derived cells for regeneration of various tissues," Journal of Pharmacological Sciences, vol. 105, no. 3, pp. 215-228, 2007.

[19] H. Niknejad, H. Peirovi, M. Jorjani, A. Ahmadiani, J. Ghanavi, and A. M. Seifalian, "Properties of the amniotic membrane for potential use in tissue engineering," European Cells and Materials, vol. 15, pp. 88-99, 2008.

[20] O. Parolini, M. Soncini, M. Evangelista, and D. Schmidt, "Amniotic membrane and amniotic fluid-derived cells: potential tools for regenerative medicine?" Regenerative Medicine, vol. 4, no. 2, pp. 275-291, 2009.

[21] J. Davis, "Skin transplantation with a review of 550 cases at the Johns Hopkins Hospital," in Johns Hopkins Hospital Report, vol. 15, 1910.

[22] N. Sabella, "Use of fetal membranes in skin grafting," Medical Records-New York, vol. 83, article 478, 1913.

[23] M. Stern, "The grafting of preserved amniotic membrane to burned and ulcerated surfaces, substituting skin grafts. A preliminary report," JAMA, vol. 60, pp. 973-994, 1913.

[24] A. De Rotth, "Plastic repair of conjunctival defects with fetal membrane," Archives of Ophthalmology, vol. 23, pp. 522-525, 1940.

[25] D. Meller, M. Pauklin, H. Thomasen, H. Westekemper, and K. P. Steuhl, "Amniotic membrane transplantation in the human eye," Deutsches Arzteblatt, vol. 108, no. 14, pp. 243248, 2011.

[26] B. Seitz, M. D. Resch, U. Schlötzer-Schrehardt, C. HofmannRummelt, R. Sauer, and F. E. Kruse, "Histopathology and ultrastructure of human corneas after amniotic membrane transplantation," Archives of Ophthalmology, vol. 124, no. 10, pp. 1487-1490, 2006.

[27] K. Kitagawa, S. Yanagisawa, K. Watanabe et al., "A hyperdry amniotic membrane patch using a tissue adhesive for corneal perforations and bleb leaks," American Journal of Ophthalmology, vol. 148, no. 3, pp. 383-389.e1, 2009.

[28] K. Kitagawa, M. Okabe, S. Yanagisawa, X. Y. Zhang, T. Nikaido, and A. Hayashi, "Use of a hyperdried cross-linked amniotic membrane as initial therapy for corneal perforations," Japanese Journal of Ophthalmology, vol. 55, no. 1, pp. 16-21, 2011.

[29] M. P. Dobreva, P. N. G. Pereira, J. Deprest, and A. Zwijsen, "On the origin of amniotic stem cells: of mice and men," International Journal of Developmental Biology, vol. 54, no. 5, pp. 761-777, 2010.

[30] B. Seitz, S. Das, R. Sauer, C. Hofmann-Rummelt, M. W. Beckmann, and F. E. Kruse, "Simultaneous amniotic membrane patch in high-risk keratoplasty," Cornea, vol. 30, no. 3, pp. 269-272, 2011.

[31] H. Shojaku, H. Takakura, M. Okabe, M. Fujisaka, Y. Watanabe, and T. Nikaido, "Effect of hyperdry amniotic membrane patches attached over the bony surface of mastoid cavities in canal wall down tympanoplasty," Laryngoscope, vol. 121, no. 9, pp. 1953-1957, 2011.

[32] D. N. Danforth and R. W. Hull, "The microscopic anatomy of the fetal membranes with particular reference to the detailed structure of the amnion," American Journal of Obstetrics and Gynecology, vol. 75, no. 3, pp. 536-550, 1958.

[33] G. L. Bourne, "The microscopic anatomy of the human amnion and chorion," American Journal of Obstetrics and Gynecology, vol. 79, no. 6, pp. 1070-1073, 1960.

[34] P. Zhao, H. Ise, M. Hongo, M. Ota, I. Konishi, and T. Nikaido, "Human amniotic mesenchymal cells have some characteristics of cardiomyocytes," Transplantation, vol. 79, no. 5, pp. 528-535, 2005.

[35] T. Tamagawa, I. Ishiwata, H. Ishikawa, and Y. Nakamura, "Induced in vitro differentiation of neural-like cells from human amnion-derived fibroblast-like cells," Human Cell, vol. 21, no. 2, pp. 38-45, 2008.

[36] T. Miki, K. Mitamura, M. A. Ross, D. B. Stolz, and S. C. Strom, "Identification of stem cell marker-positive cells by immunofluorescence in term human amnion," Journal of Reproductive Immunology, vol. 75, no. 2, pp. 91-96, 2007.

[37] T. Miki, "Amnion-derived stem cells: in quest of clinical applications," Stem Cell Research and Therapy, vol. 2, no. 3, article 25, 2011.

[38] N. Sakuragawa, K. Kakinuma, A. Kikuchi et al., "Human amnion mesenchyme cells express phenotypes of neuroglial progenitor cells," Journal of Neuroscience Research, vol. 78, no. 2, pp. 208-214, 2004.

[39] C. B. Portmann-Lanz, A. Schoeberlein, A. Huber et al., "Placental mesenchymal stem cells as potential autologous graft for pre- and perinatal neuroregeneration," American Journal of Obstetrics and Gynecology, vol. 194, no. 3, pp. 664673, 2006.

[40] T. Miki, F. Marongiu, E. C. S. Ellis et al., "Production of hepatocyte-like cells from human amnion," Methods in Molecular Biology, vol. 481, pp. 155-168, 2009.

[41] S. Takashima, H. Ise, P. Zhao, T. Akaike, and T. Nikaido, "Human amniotic epithelial cells possess hepatocyte-like characteristic and functions," Cell Structure and Function, vol. 29, no. 3, pp. 73-84, 2004.

[42] T. Tamagawa, S. Oi, I. Ishiwata, H. Ishikawa, and Y. Nakamura, "Differentiation of mesenchymal cells derived from human amniotic membranes into hepatocyte-like cells in vitro," Human Cell, vol. 20, no. 3, pp. 77-84, 2007. 
[43] F. Marongiu, R. Gramignoli, K. Dorko et al., "Hepatic differentiation of amniotic epithelial cells," Hepatology, vol. 53, no. 5, pp. 1719-1729, 2011.

[44] H. Tsuji, S. Miyoshi, Y. Ikegami et al., "Xenografted human amniotic membrane-derived mesenchymal stem cells are immunologically tolerated and transdifferentiated into cardiomyocytes," Circulation Research, vol. 106, no. 10, pp. 1613-1623, 2010.

[45] G. Bilic, S. M. Zeisberger, A. S. Mallik, R. Zimmermann, and A. H. Zisch, "Comparative characterization of cultured human term amnion epithelial and mesenchymal stromal cells for application in cell therapy," Cell Transplantation, vol. 17, no. 8, pp. 955-968, 2008.

[46] P. S. In't Anker, S. A. Scherjon, C. Kleijburg-Van Der Keur et al., "Isolation of mesenchymal stem cells of fetal or maternal origin from human placenta," Stem Cells, vol. 22, no. 7, pp. 1338-1345, 2004.

[47] J. Zhou, G. Yu, C. Cao, J. Pang, and X. Chen, "Bone morphogenetic protein-7 promotes chondrogenesis in human amniotic epithelial cells," International Orthopaedics, vol. 35, pp. 941-948, 2010.

[48] M. Amit, M. K. Carpenter, M. S. Inokuma et al., "Clonally derived human embryonic stem cell lines maintain pluripotency and proliferative potential for prolonged periods of culture," Developmental Biology, vol. 227, no. 2, pp. 271-278, 2000.

[49] A. Lange-Consiglio, B. Corradetti, D. Bizzaro et al., "Characterization and potential applications of progenitor-like cells isolated from horse amniotic membrane," Journal of Tissue Engineering and Regenerative Medicine, vol. 6, no. 8, pp. 622635, 2012.

[50] O. Parolini, F. Alviano, G. P. Bagnara et al., "Concise review: isolation and characterization of cells from human term placenta: outcome of the First International Workshop on Placenta Derived Stem Cells," Stem Cells, vol. 26, no. 2, pp. 300-311, 2008.

[51] J. Kim, H. M. Kang, H. Kim et al., "Ex vivo characteristics of human amniotic membrane-derived stem cells," Cloning and Stem Cells, vol. 9, no. 4, pp. 581-594, 2007.

[52] J. M. Miranda-Sayago, N. Fernández-Arcas, C. Benito, A. Reyes-Engel, J. Carrera, and A. Alonso, "Lifespan of human amniotic fluid-derived multipotent mesenchymal stromal cells," Cytotherapy, vol. 13, no. 5, pp. 572-581, 2011.

[53] M. F. Pera and A. O. Trounson, "Human embryonic stem cells: prospects for development," Development, vol. 131, no. 22, pp. 5515-5525, 2004.

[54] J. A. Thomson, J. Itskovitz-Eldor, S. S. Shapiro et al., "Embryonic stem cell lines derived from human blastocysts," Science, vol. 282, no. 5391, pp. 1145-1147, 1998.

[55] S. D. Schwartz, J.-P. Hubschman, G. Heilwell et al., "Embryonic stem cell trials for macular degeneration: a preliminary report," The Lancet, vol. 379, no. 9817, pp. 713-720, 2012.

[56] A. M. Yeager, H. S. Singer, and J. R. Buck, "A therapeutic trial of amniotic epithelial cell implantation in patients with lysosomal storage diseases," American Journal of Medical Genetics, vol. 22, no. 2, pp. 347-355, 1985.

[57] R. Langer and J. P. Vacanti, “Tissue engineering," Science, vol. 260, no. 5110, pp. 920-926, 1993.

[58] M. Chen, X. Wang, Z. Ye, Y. Zhang, Y. Zhou, and W. S. Tan, “A modular approach to the engineering of a centimeter-sized bone tissue construct with human amniotic mesenchymal stem cells-laden microcarriers," Biomaterials, vol. 32, pp. 7532-7542, 2011.
[59] B. Barboni, V. Curini, V. Russo et al., "Indirect co-culture with tendons or tenocytes can program amniotic epithelial cells towards stepwise tenogenic differentiation," PLOS ONE, vol. 7, no. 2, Article ID e30974, 2012.

[60] H. Li, Y. Chu, Z. Zhang et al., "Construction of bilayered tissue-engineered skin with human amniotic mesenchymal cells and human amniotic epithelial cells," Artificial Organs. In press.

[61] U. Manuelpillai, J. Tchongue, D. Lourensz et al., "Transplantation of human amnion epithelial cells reduces hepatic fibrosis in immunocompetent CCl4-treated mice," Cell Transplantation, vol. 19, no. 9, pp. 1157-1168, 2010.

[62] D. Zhang, M. Jiang, and D. Miao, “Transplanted human amniotic membrane-derived mesenchymal stem cells ameliorate carbon tetrachloride-induced liver cirrhosis in mouse," PLoS ONE, vol. 6, no. 2, Article ID e16789, 2011.

[63] K. L. Fujimoto, T. Miki, L. J. Liu et al., "Naive rat amnionderived cell transplantation improved left ventricular function and reduced myocardial scar of postinfarcted heart," Cell Transplantation, vol. 18, no. 4, pp. 477-486, 2009.

[64] J. P. Wei, T. S. Zhang, S. Kawa et al., "Human amnionisolated cells normalize blood glucose in streptozotocininduced diabetic mice," Cell Transplantation, vol. 12, no. 5, pp. 545-552, 2003.

[65] Y. Hou, Q. Huang, T. Liu, and L. Guo, "Human amnion epithelial cells can be induced to differentiate into functional insulin-producing cells," Acta Biochimica et Biophysica Sinica, vol. 40, no. 9, pp. 830-839, 2008.

[66] S. S. Kadam, M. Sudhakar, P. D. Nair, and R. R. Bhonde, "Reversal of experimental diabetes in mice by transplantation of neo-islets generated from human amnion-derived mesenchymal stromal cells using immuno-isolatory macrocapsules," Cytotherapy, vol. 12, no. 8, pp. 982-991, 2010.

[67] T. Miki and S. C. Strom, "Amnion-derived pluripotent/ multipotent stem cells," Stem Cell Reviews, vol. 2, no. 2, pp. 133-142, 2006.

[68] S. Díaz-Prado, E. Muiños-López, T. Hermida-Gómez et al., "Multilineage differentiation potential of cells isolated from the human amniotic membrane," Journal of Cellular Biochemistry, vol. 111, no. 4, pp. 846-857, 2010.

[69] S. Díaz-Prado, E. Muiños-López, T. Hermida-Gómez et al., "Human amniotic membrane as an alternative source of stem cells for regenerative medicine," Differentiation, vol. 81, no. 3, pp. 162-171, 2011.

[70] D. R. Abramovich and K. R. Page, "Pathways of water transfer between liquor amnii and the fetoplacental unit at term," European Journal of Obstetrics and Gynecology and Reproductive Biology, vol. 3, no. 5, pp. 155-158, 1973.

[71] F. K. Lotgering and H. C. S. Wallenburg, "Mechanisms of production and clearance of amniotic fluid," Seminars in Perinatology, vol. 10, no. 2, pp. 94-102, 1986.

[72] R. A. Brace, "Amniotic fluid dynamics," in Maternal Fetal Medicine, Principles and Practice, R. K. Creasy, R. Resnik, and J. D. Iams, Eds., pp. 45-53, Saunders, Philadelphia, Pa, USA, 5th edition, 2004.

[73] M. A. Underwood, W. M. Gilbert, and M. P. Sherman, "Amniotic fluid: not just fetal urine anymore," Journal of Perinatology, vol. 25, no. 5, pp. 341-348, 2005.

[74] P. E. Michel, D. Crettaz, P. Morier et al., "Proteome analysis of human plasma and amniotic fluid by Off-Gel isoelectric focusing followed by nano-LC-MS/MS," Electrophoresis, vol. 27, no. 5-6, pp. 1169-1181, 2006. 
[75] S. J. Park, W. G. Yoon, J. S. Song et al., "Proteome analysis of human amnion and amniotic fluid by two-dimensional electrophoresis and matrix-assisted laser desorption/ionization time-of-flight mass spectrometry," Proteomics, vol. 6, no. 1, pp. 349-363, 2006.

[76] G. Tsangaris, R. Weitzdörfer, D. Pollak, G. Lubec, and M. Fountoulakis, "The amniotic fluid cell proteome," Electrophoresis, vol. 26, no. 6, pp. 1168-1173, 2005.

[77] R. A. Brace, M. G. Ross, and J. E. Robillard, Fetal and Neonatal Body Fluids: The Scientific Basis for Clinical Practice, Perinatology Press, Ithaca, NY, USA, 1989.

[78] F. Torricelli, L. Brizzi, P. A. Bernabei et al., "Identification of hematopoietic progenitor cells in human amniotic fluid before the 12th week of gestation," Italian Journal of Anatomy and Embryology, vol. 98, no. 2, pp. 119-126, 1993.

[79] S. Da Sacco, S. Sedrakyan, F. Boldrin et al., "Human amniotic fluid as a potential new source of organ specific precursor cells for future regenerative medicine applications," Journal of Urology, vol. 183, no. 3, pp. 1193-1200, 2010.

[80] R. Wapner, "A multicenter, prospective, masked comparison of chromosomal microarray with standard karyotyping for routine and high risk prenatal diagnosis," American Journal of Obstetrics and Gynecology, vol. 206, article S2, 2012.

[81] M. Rosner, H. Dolznig, K. Schipany, M. Mikula, O. Brandau, and M. Hengstschläger, "Human amniotic fluid stem cells as a model for functional studies of genes involved in human genetic diseases or oncogenesis," Oncotarget, vol. 2, no. 9, pp. 705-712, 2011.

[82] M. Rosner, K. Schipany, B. Shanmugasundaram, G. Lubec, and M. Hengstschläger, "Amniotic fluid stem cells: future perspectives," Stem Cells International, vol. 2012, Article ID 741810, 6 pages, 2012.

[83] M. Rosner, N. Siegel, C. Fuchs, N. Slabina, H. Dolznig, and M. Hengstschläger, "Efficient siRNA-mediated prolonged gene silencing in human amniotic fluid stem cells," Nature Protocols, vol. 5, no. 6, pp. 1081-1095, 2010.

[84] C. Fuchs, M. Rosner, H. Dolznig, M. Mikula, N. Kramer, and M. Hengstschläger, "Tuberin and PRAS40 are anti-apoptotic gatekeepers during early human amniotic fluid stem-cell differentiation," Human Molecular Genetics, vol. 21, no. 5, pp. 1049-1061, 2012.

[85] A. R. Prusa and M. Hengstschläger, "Amniotic fluid cells and human stem cell research-a new connection," Medical Science Monitor, vol. 8, no. 11, pp. RA253-RA257, 2002.

[86] A. R. Prusa, E. Marton, M. Rosner, G. Bernaschek, and M. Hengstschläger, "Oct-4-expressing cells in human amniotic fluid: a new source for stem cell research?" Human Reproduction, vol. 18, no. 7, pp. 1489-1493, 2003.

[87] P. S. In 't Anker, S. A. Scherjon, C. Kleijburg-van der Keur et al., "Amniotic fluid as a novel source of mesenchymal stem cells for therapeutic transplantation," Blood, vol. 102, no. 4, pp. 1548-1549, 2003.

[88] M. S. Tsai, S. M. Hwang, Y. L. Tsai, F. C. Cheng, J. L. Lee, and Y. J. Chang, "Clonal amniotic fluid-derived stem cells express characteristics of both mesenchymal and neural stem cells," Biology of Reproduction, vol. 74, no. 3, pp. 545-551, 2006.

[89] L. Perin, S. Sedrakyan, S. Da Sacco, and R. De Filippo, "Characterization of human amniotic fluid stem cells and their pluripotential capability," Methods in Cell Biology, vol. 86, pp. 85-99, 2008.

[90] A. Valli, M. Rosner, C. Fuchs et al., "Embryoid body formation of human amniotic fluid stem cells depends on mTOR," Oncogene, vol. 29, no. 7, pp. 966-977, 2010.
[91] T. Phermthai, Y. Odglun, S. Julavijitphong et al., "A novel method to derive amniotic fluid stem cells for therapeutic purposes," BMC Cell Biology, vol. 11, article 79, 2010.

[92] N. Siegel, M. Rosner, M. Unbekandt et al., "Contribution of human amniotic fluid stem cells to renal tissue formation depends on mTOR," Human Molecular Genetics, vol. 19, no. 17, pp. 3320-3331, 2010.

[93] A. Jezierski, A. Gruslin, R. Tremblay et al., "Probing stemness and neural commitment in human amniotic fluid cells," Stem Cell Reviews and Reports, vol. 6, no. 2, pp. 199-214, 2010.

[94] A. Kaviani, T. E. Perry, A. Dzakovic, R. W. Jennings, M. M. Ziegler, and D. O. Fauza, "The amniotic fluid as a source of cells for fetal tissue engineering," Journal of Pediatric Surgery, vol. 36, no. 11, pp. 1662-1665, 2001.

[95] A. Kaviani, K. Guleserian, T. E. Perry, R. W. Jennings, M. M. Ziegler, and D. O. Fauza, "Fetal tissue engineering from amniotic fluid," Journal of the American College of Surgeons, vol. 196, no. 4, pp. 592-597, 2003.

[96] S. M. Kunisaki, D. A. Freedman, and D. O. Fauza, "Fetal tracheal reconstruction with cartilaginous grafts engineered from mesenchymal amniocytes," Journal of Pediatric Surgery, vol. 41, no. 4, pp. 675-682, 2006.

[97] J. R. Fuchs, A. Kaviani, J. T. Oh et al., "Diaphragmatic reconstruction with autologous tendon engineered from mesenchymal amniocytes," Journal of Pediatric Surgery, vol. 39, no. 6, pp. 834-838, 2004.

[98] S. M. Kunisaki, J. R. Fuchs, A. Kaviani et al., "Diaphragmatic repair through fetal tissue engineering: a comparison between mesenchymal amniocyte- and myoblast-based constructs," Journal of Pediatric Surgery, vol. 41, no. 1, pp. 34-39, 2006.

[99] S. A. Steigman, A. Ahmed, R. M. Shanti, R. S. Tuan, C. Valim, and D. O. Fauza, "Sternal repair with bone grafts engineered from amniotic mesenchymal stem cells," Journal of Pediatric Surgery, vol. 44, no. 6, pp. 1120-1126, 2009.

[100] J. D. Klein, C. G. B. Turner, A. Ahmed, S. A. Steigman, D. Zurakowski, and D. O. Fauza, "Chest wall repair with engineered fetal bone grafts: an efficacy analysis in an autologous leporine model," Journal of Pediatric Surgery, vol. 45, no. 6, pp. 1354-1360, 2010.

[101] A. Peister, E. R. Deutsch, Y. Kolambkar, D. W. Hutmacher, and R. E. Guldberg, "Amniotic fluid stem cells produce robust mineral deposits on biodegradable scaffolds," Tissue Engineering-Part A, vol. 15, no. 10, pp. 3129-3138, 2009.

[102] D. Schmidt, J. Achermann, B. Odermatt et al., "Prenatally fabricated autologous human living heart valves based on amniotic fluid-derived progenitor cells as single cell source," Circulation, vol. 116, no. 11, supplement, pp. I64-I70, 2007.

[103] D. Schmidt, J. Achermann, B. Odermatt, M. Genoni, G. Zund, and S. P. Hoerstrup, "Cryopreserved amniotic fluidderived cells: a life-long autologous fetal stem cell source for heart valve tissue engineering," Journal of Heart Valve Disease, vol. 17, no. 4, pp. 446-455, 2008.

[104] B. Weber, M. Y. Emmert, L. Behr et al., "Prenatally engineered autologous amniotic fluid stem cell-based heart valves in the fetal circulation," Biomaterials, vol. 33, no. 16, pp. 4031-4043, 2012.

[105] P. De Coppi, A. Callegari, A. Chiavegato et al., "Amniotic fluid and bone marrow derived mesenchymal stem cells can be converted to smooth muscle cells in the cryo-injured rat bladder and prevent compensatory hypertrophy of surviving smooth muscle cells," Journal of Urology, vol. 177, no. 1, pp. 369-376, 2007. 
[106] L. Perin, S. Sedrakyan, S. Giuliani et al., "Protective effect of human amniotic fluid stem cells in an immunodeficient mouse model of acute tubular necrosis," PLOS ONE, vol. 5, no. 2, Article ID e9357, 2010.

[107] G. Carraro, L. Perin, S. Sedrakyan et al., "Human amniotic fluid stem cells can integrate and differentiate into epithelial lung lineages," Stem Cells, vol. 26, no. 11, pp. 2902-2911, 2008.

[108] S. Bollini, M. Pozzobon, M. Nobles et al., "In Vitro and in vivo cardiomyogenic differentiation of amniotic fluid stem cells," Stem Cell Reviews and Reports, vol. 7, no. 2, pp. 364380, 2011.

[109] A. K. Rehni, N. Singh, A. S. Jaggi, and M. Singh, "Amniotic fluid derived stem cells ameliorate focal cerebral ischaemiareperfusion injury induced behavioural deficits in mice," Behavioural Brain Research, vol. 183, no. 1, pp. 95-100, 2007.

[110] S. Cipriani, D. Bonini, E. Marchina et al., "Mesenchymal cells from human amniotic fluid survive and migrate after transplantation into adult rat brain," Cell Biology International, vol. 31, no. 8, pp. 845-850, 2007.

[111] N. Tajiri, S. Acosta, L. E. Glover et al., "Intravenous grafts of amniotic fluid-derived stem cells induce endogenous cell proliferation and attenuate behavioral deficits in ischemic stroke rats," PLoS ONE, vol. 7, no. 8, Article ID e43779, 2012.

[112] A. Jezierski, K. Rennie, R. Tremblay et al., "Human amniotic fluid cells form functional gap junctions with cortical cells," Stem Cells International, vol. 2012, Article ID 607161, 16 pages, 2012.

[113] H. C. Pan, D. Y. Yang, Y. T. Chiu et al., "Enhanced regeneration in injured sciatic nerve by human amniotic mesenchymal stem cell," Journal of Clinical Neuroscience, vol. 13, no. 5, pp. 570-575, 2006.

[114] H. C. Pan, F. C. Cheng, C. J. Chen et al., "Post-injury regeneration in rat sciatic nerve facilitated by neurotrophic factors secreted by amniotic fluid mesenchymal stem cells," Journal of Clinical Neuroscience, vol. 14, no. 11, pp. 10891098, 2007.

[115] H. C. Pan, C. J. Chen, F. C. Cheng et al., "Combination of GCSF administration and human amniotic fluid mesenchymal stem cell transplantation promotes peripheral nerve regeneration," Neurochemical Research, vol. 34, no. 3, pp. 518-527, 2009.

[116] H. C. Pan, C. S. Chin, D. Y. Yang et al., "Human amniotic fluid mesenchymal stem cells in combination with hyperbaric oxygen augment peripheral nerve regeneration," Neurochemical Research, vol. 34, no. 7, pp. 1304-1316, 2009.

[117] H. C. Pan, D. Y. Yang, S. P. Ho et al., "Escalated regeneration in sciatic nerve crush injury by the combined therapy of human amniotic fluid mesenchymal stem cells and fermented soybean extracts, Natto," Journal of Biomedical Science, vol. 16, no. 1, article 75, 2009.

[118] D.-Y. Yang, M.-L. Sheu, H.-L. Su et al., "Dual regeneration of muscle and nerve by intravenous administration of human amniotic fluid-derived mesenchymal stem cells regulated by stromal cell-derived factor- $1 \alpha$ in a sciatic nerve injury model: laboratory investigation," Journal of Neurosurgery, vol. 116, no. 6, pp. 1357-1367, 2012.

[119] Y. C. Yeh, W. Y. Lee, C. L. Yu et al., "Cardiac repair with injectable cell sheet fragments of human amniotic fluid stem cells in an immune-suppressed rat model," Biomaterials, vol. 31, no. 25, pp. 6444-6453, 2010.

[120] Y. C. Yeh, H. J. Wei, W. Y. Lee et al., "Cellular cardiomyoplasty with human amniotic fluid stem cells: in vitro and in vivo studies," Tissue Engineering-Part A, vol. 16, no. 6, pp. 19251936, 2010.

[121] W. Y. Lee, H. J. Wei, W. W. Lin et al., "Enhancement of cell retention and functional benefits in myocardial infarction using human amniotic-fluid stem-cell bodies enriched with endogenous ECM," Biomaterials, vol. 32, no. 24, pp. 55585567, 2011.

[122] L. Iop, A. Chiavegato, A. Callegari et al., "Different cardiovascular potential of adult- and fetal-type mesenchymal stem cells in a rat model of heart cryoinjury," Cell Transplantation, vol. 17, no. 6, pp. 679-694, 2008.

[123] A. Angelini, C. Castellani, B. Ravara et al., "Stem-cell therapy in an experimental model of pulmonary hypertension and right heart failure: role of paracrine and neurohormonal milieu in the remodeling process," Journal of Heart and Lung Transplantation, vol. 30, no. 11, pp. 1281-1293, 2011.

[124] M. Piccoli, C. Franzin, E. Bertin et al., "Amniotic fluid stem cells restore the muscle cell niche in a HSA-Cre, $\mathrm{Smn}^{\text {F7/F7 }}$ mouse model," Stem Cells, vol. 30, no. 8, pp. 1675-1684, 2012.

[125] M. Ghionzoli, M. Cananzi, A. Zani et al., "Amniotic fluid stem cell migration after intraperitoneal injection in pup rats: implication for therapy," Pediatric Surgery International, vol. 26, no. 1, pp. 79-84, 2010.

[126] D. Liekens, L. Lewi, J. Jani et al., "Enrichment of collagen plugs with platelets and amniotic fluid cells increases cell proliferation in sealed iatrogenic membrane defects in the foetal rabbit model," Prenatal Diagnosis, vol. 28, no. 6, pp. 503-507, 2008.

[127] S. W. Steven Shaw, S. Bollini, K. A. Nader et al., "Autologous transplantation of amniotic fluid-derived mesenchymal stem cells into sheep fetuses," Cell Transplantation, vol. 20, no. 7, pp. 1015-1031, 2011.

[128] A. Ditadi, P. De Coppi, O. Picone et al., "Human and murine amniotic fluid c-Kit+Lin- cells display hematopoietic activity," Blood, vol. 113, no. 17, pp. 3953-3960, 2009.

[129] C. Rota, B. Imberti, M. Pozzobon et al., "Human amniotic fluid stem cell preconditioning improves their regenerative potential," Stem Cells and Development, vol. 21, no. 11, pp. 1911-1923, 2012.

[130] M. Toselli, E. Cerbai, F. Rossi, and E. Cattaneo, "Do amniotic fluid-derived stem cells differentiate into neurons in vitro?" Nature Biotechnology, vol. 26, no. 3, pp. 269-270, 2008.

[131] M. Rosner, M. Mikula, A. Preitschopf, M. Feichtinger, K. Schipany, and M. Hengstschläger, "Neurogenic differentiation of amniotic fluid stem cells," Amino Acids, vol. 42, pp. 1591-1596, 2011.

[132] W. Prasongchean, M. Bagni, C. Calzarossa, P. De Coppi, and P. Ferretti, "Amniotic fluid stem cells increase embryo survival following injury," Stem Cells and Development, vol. 21, no. 5, pp. 675-688, 2012.

[133] K. Kakishita, N. Nakao, N. Sakuragawa, and T. Itakura, "Implantation of human amniotic epithelial cells prevents the degeneration of nigral dopamine neurons in rats with 6hydroxydopamine lesions," Brain Research, vol. 980, no. 1, pp. 48-56, 2003.

[134] K. Kakishita, M. A. Elwan, N. Nakao, T. Itakura, and N. Sakuragawa, "Human amniotic epithelial cells produce dopamine and survive after implantation into the striatum of a rat model of Parkinson's disease: a potential source of donor for transplantation therapy," Experimental Neurology, vol. 165, no. 1, pp. 27-34, 2000.

[135] X. X. Yang, S. R. Xue, W. L. Dong, and Y. Kong, "Therapeutic effect of human amniotic epithelial cell transplantation 
into the lateral ventricle of hemiparkinsonian rats," Chinese Medical Journal, vol. 122, no. 20, pp. 2449-2454, 2009.

[136] N. Joyce, G. Annett, L. Wirthlin, S. Olson, G. Bauer, and J. A. Nolta, "Mesenchymal stem cells for the treatment of neurodegenerative disease," Regenerative Medicine, vol. 5, no. 6, pp. 933-946, 2010.

[137] D. De Feo, A. Merlini, C. Laterza, and G. Martino, "Neural stem cell transplantation in central nervous system disorders: from cell replacement to neuroprotection," Current Opinion in Neurology, vol. 25, no. 3, pp. 322-333, 2012.

[138] W. Dai, G. L. Kay, A. J. Jyrala, and R. A. Kloner, "Experience from experimental cell transplantation therapy of myocardial infarction: what have we learned?" Cell Transplantation. In press.

[139] M. Teodelinda, C. Michele, C. Sebastiano, C. Ranieri, and G. Chiara, "Amniotic liquid derived stem cells as reservoir of secreted angiogenic factors capable of stimulating neoarteriogenesis in an ischemic model," Biomaterials, vol. 32, no. 15, pp. 3689-3699, 2011.

[140] H. G. Kim and O. H. Choi, "Neovascularization in a mouse model via stem cells derived from human fetal amniotic membranes," Heart and Vessels, vol. 26, no. 2, pp. 196-205, 2011.

[141] T. Mirabella, J. Hartinger, C. Lorandi, C. Gentili, M. Van Griensven, and R. Cancedda, "Proangiogenic soluble factors from amniotic fluid stem cells mediate the recruitment of endothelial progenitors in a model of ischemic fasciocutaneous flap," Stem Cells and Development, vol. 21, no. 12, pp. 2179-2188, 2012.

[142] B. S. Yoon, J. H. Moon, E. K. Jun et al., "Secretory profiles and wound healing effects of human amniotic fluid-derived mesenchymal stem cells," Stem Cells and Development, vol. 19, no. 6, pp. 887-902, 2010.

[143] S. Uchida, Y. Inanaga, M. Kobayashi, S. Hurukawa, M. Araie, and N. Sakuragawa, "Neurotrophic function of conditioned medium from human amniotic epithelial cells," Journal of Neuroscience Research, vol. 62, no. 4, pp. 585-590, 2000.

[144] K. Kamiya, M. Wang, S. Uchida et al., "Topical application of culture supernatant from human amniotic epithelial cells suppresses inflammatory reactions in cornea," Experimental Eye Research, vol. 80, no. 5, pp. 671-679, 2005.

[145] E. C. Moorefield, E. E. McKee, L. Solchaga et al., "Cloned, CD117 selected human amniotic fluid stem cells are capable of modulating the immune response," PLoS ONE, vol. 6, no. 10, Article ID e26535, 2011.

[146] V. Sankar and R. Muthusamy, "Role of human amniotic epithelial cell transplantation in spinal cord injury repair research," Neuroscience, vol. 118, no. 1, pp. 11-17, 2003.

[147] F. C. Cheng, M. H. Tai, M. L. Sheu et al., "Enhancement of regeneration with glia cell line-derived neurotrophic factortransduced human amniotic fluid mesenchymal stem cells after sciatic nerve crush injury," Journal of Neurosurgery, vol. 112 , no. 4, pp. 868-879, 2010.

[148] T. Liu, J. Wu, Q. Huang et al., "Human amniotic epithelial cells ameliorate behavioral dysfunction and reduce infarct size in the rat middle cerebral artery occlusion model," Shock, vol. 29, no. 5, pp. 603-611, 2008.

[149] J. Tao, F. Ji, B. Liu, F. Wang, F. Dong, and Y. Zhu, "Improvement of deficits by transplantation of lentiviral vector-modified human amniotic mesenchymal cells after cerebral ischemia in rats," Brain Research, vol. 1448, pp. 110, 2012.

[150] J. Yin, J. K. Kim, J. H. Moon et al., "HMSC-mediated concurrent delivery of endostatin and carboxylesterase to mouse xenografts suppresses glioma initiation and recurrence," Molecular Therapy, vol. 19, no. 6, pp. 1161-1169, 2011.

[151] N.-H. Kang, K.-A. Hwang, B.-R. Yi et al., "Human amniotic fluid-derived stem cells expressing cytosine deaminase and thymidine kinase inhibits the growth of breast cancer cells in cellular and xenograft mouse models," Cancer Gene Therapy, vol. 19, no. 6, pp. 412-419, 2012.

[152] P. R. Brink, V. Valiunas, C. Gordon, M. R. Rosen, and I. S. Cohen, "Can gap junctions deliver?" Biochimica et Biophysica Acta, vol. 1818, no. 8, pp. 2076-2081, 2012.

[153] N. Rouach, E. Avignone, W. Même et al., "Gap junctions and connexin expression in the normal and pathological central nervous system," Biology of the Cell, vol. 94, no. 7-8, pp. 457475, 2002.

[154] A. Ohsumi, H. Nawashiro, N. Otani, H. Ooigawa, T. Toyooka, and K. Shima, "Temporal and spatial profile of phosphorylated connexin 43 after traumatic brain injury in rats," Journal of Neurotrauma, vol. 27, no. 7, pp. 1255-1263, 2010.

[155] C. Haupt, O. W. Witte, and C. Frahm, "Up-regulation of Connexin43 in the glial scar following photothrombotic ischemic injury," Molecular and Cellular Neuroscience, vol. 35, no. 1, pp. 89-99, 2007.

[156] M. G. Roubelakis, V. Bitsika, D. Zagoura et al., "In vitro and in vivo properties of distinct populations of amniotic fluid mesenchymal progenitor cells," Journal of Cellular and Molecular Medicine, vol. 15, no. 9, pp. 1896-1913, 2011.

[157] Y. W. Kim, H. J. Kim, S. M. Bae et al., "Time-course transcriptional profiling of human amniotic fluid-derived stem cells using microarray," Cancer Treatment and Research, vol. 42, pp. 82-94, 2010.

[158] S. Arnhold, S. Glüer, K. Hartmann et al., "Amniotic-fluid stem cells: growth dynamics and differentiation potential after a CD-117-based selection procedure," Stem Cells International, vol. 2011, Article ID 715341, 12 pages, 2011.

[159] J. Bai, Y. Wang, L. Liu et al., "Human amniotic fluid-derived

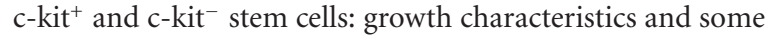
differentiation potential capacities comparison," Cytotechnology. In press.

[160] X. Wang, Y. Lu, H. Zhang et al., "Distinct efficacy of predifferentiated versus intact fetal mesencephalon-derived human neural progenitor cells in alleviating rat model of Parkinson's disease," International Journal of Developmental Neuroscience, vol. 22, no. 4, pp. 175-183, 2004.

[161] H. Aurich, M. Sgodda, P. Kaltwaßer et al., "Hepatocyte differentiation of mesenchymal stem cells from human adipose tissue in vitro promotes hepatic integration in vivo," Gut, vol. 58, no. 4, pp. 570-581, 2009.

[162] C. A. Akle, M. Adinolfi, and K. I. Welsh, "Immunogenicity of human amniotic epithelial cells after transplantation into volunteers," The Lancet, vol. 2, no. 8254, pp. 1003-1005, 1981.

[163] A. Chiavegato, S. Bollini, M. Pozzobon et al., "Human amniotic fluid-derived stem cells are rejected after transplantation in the myocardium of normal, ischemic, immunosuppressed or immuno-deficient rat," Journal of Molecular and Cellular Cardiology, vol. 42, no. 4, pp. 746-759, 2007.

[164] M. Wang, A. Yoshida, H. Kawashima, M. Ishizaki, H. Takahashi, and J. Hori, "Immunogenicity and antigenicity of allogeneic amniotic epithelial transplants grafted to the cornea, conjunctiva, and anterior chamber," Investigative Ophthalmology and Visual Science, vol. 47, no. 4, pp. 1522-1532, 2006. 
[165] A. E. Donaldson, J. Cai, M. Yang, and L. Iacovitti, "Human amniotic fluid stem cells do not differentiate into dopamine neurons in vitro or after transplantation in vivo," Stem Cells and Development, vol. 18, no. 7, pp. 1003-1011, 2009.

[166] R. Soler, C. Fllhase, A. Hanson, L. Campeau, C. Santos, and K.-E. Andersson, "Stem cell therapy ameliorates bladder dysfunction in an animal model of parkinson disease," Journal of Urology, vol. 187, no. 4, pp. 1491-1497, 2012.

[167] R. J. Swijnenburg, S. Schrepfer, F. Cao et al., "In vivo imaging of embryonic stem cells reveals patterns of survival and immune rejection following transplantation," Stem Cells and Development, vol. 17, no. 6, pp. 1023-1029, 2008. 

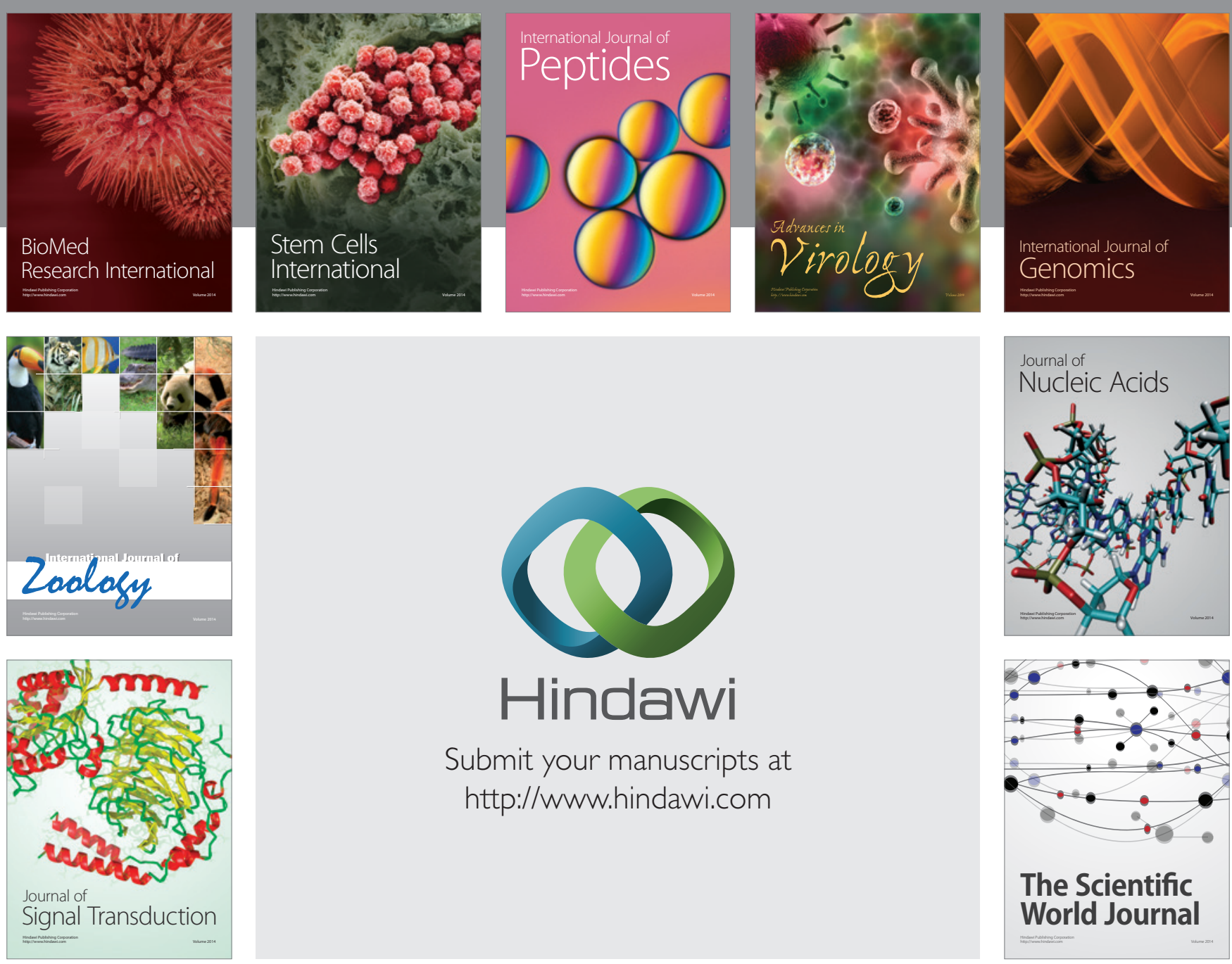

Submit your manuscripts at

http://www.hindawi.com
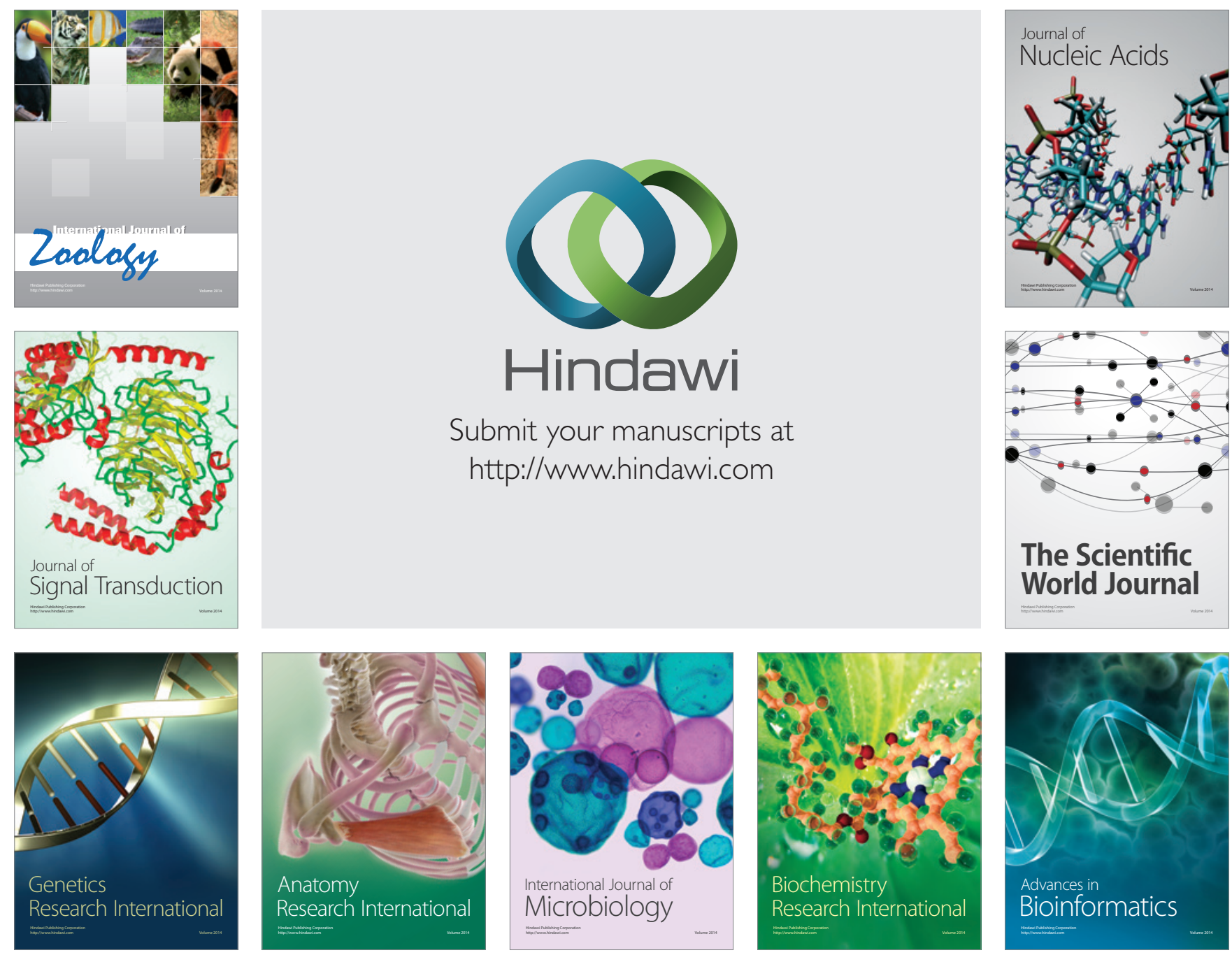

The Scientific World Journal
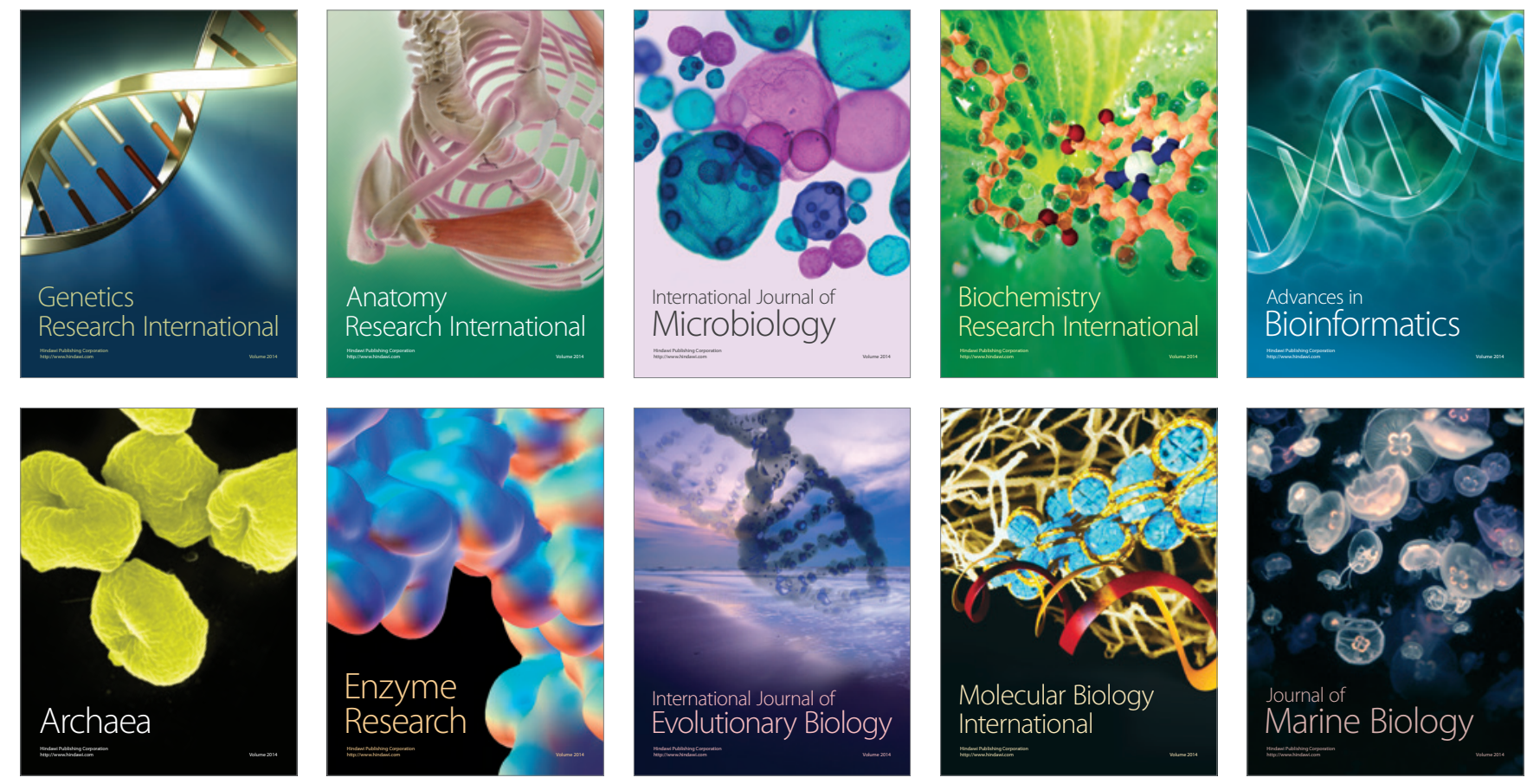